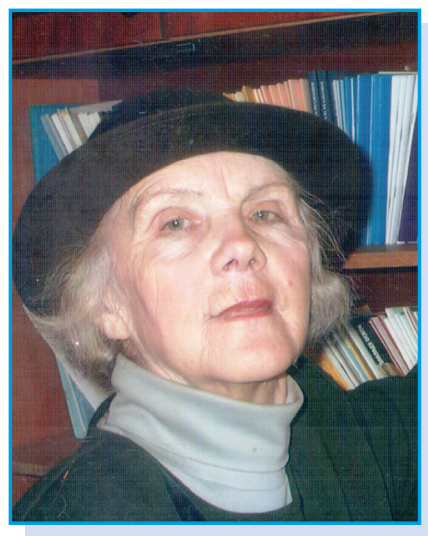

Барановська Олена Володимирівна -

кандидат педагогічних наук, стариий науковий співробітник відділу дидактики Інституту педагогіки НАПН Украӥни.

Коло наукових інтересів: фундаменталізація, гуманітаризація, інтеграція навчання, педагогічні технології, інформаційні компетентності, форми й методи навчання. Автор має понад 120 наукових публікацій, серед яких розділи в колективних монографіях, науково-методичний посібник, програми формування інформаційних умінь в учнів, методичні рекомендаціі, навчальні програми та методичні рекомендації для студентів, статті у фахових виданнях.

e-mail:baranovska@i.ua

\section{Паламарчук Валентина Федорівна -}

доктор педагогічних наук, професор, науковий консультант гімназії «Троєщина» Деснянського району м. Києва.

Коло наукових інтересів: педагогічна прогностика, педагоічна інноватика, освітній менеджмент, педагогічні технооогіi, взаємозв'язок навчання й розвитку. Заслужений праців作

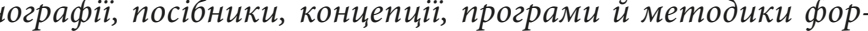
уання чанн, гімназійнї освіти, спеикурси, навчальні програми, науково-методичні посібники, статті у бахових виданнях. Створила власну наукову школу, ї̈ численні учні працюють у різних галузях освіти України.

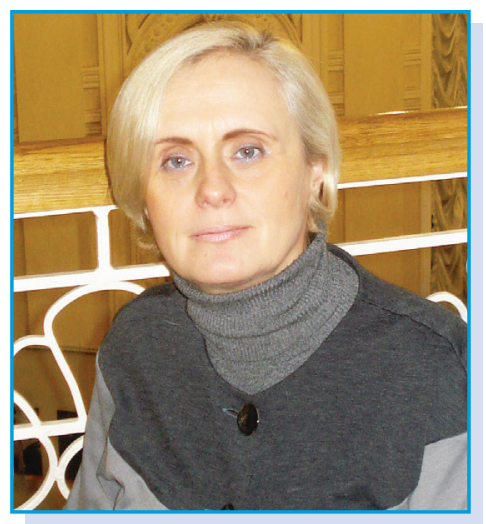

DOI 10.32405/2411-1317-2018-3-60-66 УДК 373.5.13:37.02

\title{
ПЕДАГОГІЧНІ ТЕХНОЛОГІї НАВЧАННЯ В УМОВАХ НОВОї УКРАЇНСЬКОї ШКОЛИ: BEКTOP РОЗВИТКУ
}

Стаття присвячена проблемі технологізації освітнього процесу в умовах нової української школи, що сприятиме підвищенню його якості, глибшому використанню потенціалу закладів загальної середньої освіти, ширшому впровадженню у педагогічний процес інноваційних підходів, сучасних розвивальних засобів, методів, форм навчання. У статті проаналізовано предмет педагогічної технології, розглядаються сутність та іï види, різні аспекти впровадження технологічного підходу в закладах загальної середньої освіти в умовах профільного навчання. Доводиться важливість теорії педагогічної технології для нової української школи, необхідність пошуку раціональних шляхів навчання, розробки сучасних тенденцій, базових принципів і обгрунтування особливостей їх реалізації в умовах нової української школи.

Ключові слова: нова українська школа; профільне навчання; педагогічна технологія; інтелектуальний розвиток особистості. 
Постановка проблеми. У центрі уваги нової української школи має бути творча особистість, головними якостями якої мають стати духовність, громадянськість, інтелектуальність, конкурентоспроможність. Тому глобальні завдання націлені на перебудову закладів загальної середньої освіти як структурно, так і якісно. Передумовою успіху будь-якого закладу освіти є визначення мети і прогнозованих результатів освітнього процесу. Закономірно, що в епоху активних змін у педагогічний лексикон міцно увійшло поняття педагогічної технології, алгоритм розвитку якої закладено в основному освітньому документі - Законі України «Про освіту». Трансформація терміну від «технології в навчанні» до «технології освіти», а потім до «педагогічної технології» відповідає зміні його змісту, що охоплює відповідні періоди розвитку дидактики. На зміну окремим активним формам і методам навчання, які роблять навчальний процес розірваним на частини, приходять цілісні педагогічні технології взагалі і технології навчання зокрема. Поняття «педагогічна технологія» на сучасному етапі має відображувати прийняту в країні систему освіти, ії цільову і змістову спрямованість, організаційну структуру. Зміна соціально-економічної ситуації в країні зумовлює необхідність упровадження таких освітніх технологій, які б забезпечили ефективну підготовку учнівської молоді до входження в соціум, адаптацію до існуючих реалій та здатність до активної творчої діяльності. Тому сучасні педагогічні технології мають вибудовуватись на основі чіткого планування, моделювання, структурування, систематизації та мати на меті виховання розвиток компетентної творчої особистості.

Аналіз останніх досліджень і публікацій. Проблемі педагогічних технологій в дидактичній науці і практиці присвячено достатньо багато уваги, але їхня систематизація і створення дидактичної моделі реалізації педагогічних технологій в умовах профільного навчання $є$ новим напрямком дослідження. У Законі «Про освіту» засадами державної політики у сфері освіти та принципами освітньої діяльності названо, зокрема, необхідність інтеграції у міжнародний освітній та науковий простір, єдність навчання, виховання та розвитку, що неможливо без сучасних педагогічних технологій [6].

Поняття «педагогічна технологія» стало впроваджуватися у педагогічну науку з 60-х років XX століття. Дослідженням сутності педагогічних технологій, розроблення їхніх класифікацій, видів займався ряд дослідників: В. Беспалько, Е. Бурцева, Л. Загрекова, М. Кларин, М. Махмутов та інші.

Поняття «педагогічна технологія» трактується по-різному, у залежності від розуміння авторами-розробниками мети, сутності і структури педагогічного процесу, критеріїв та підходів, його складових та результатів. Загальна установка педагогічної технології - вирішувати поставлену дидактичну проблему із заданими цілями, метою навчання та чітко визначеною структурою реалізації. Поняття «педагогічна технологія» включає в себе не тільки сукупність методів, прийомів та способів навчання, а й педагогічну майстерність, творчий підхід до навчання та виховання учнів, створення ситуації для саморозвитку і успіху.

На сучасному етапі проблема використання технологій в освітньому процесі закладів загальної середньої освіти розглядається за різними аспектами, але не системно. Науковці з різних позицій розглядають сутність і види педагогічних технологій та проблему впровадження технологічного підходу в закладах загальної середньої освіти в умовах профільного навчання. Різноманітні проблеми прогнозування, змісту і технологій загальної середньої освіти висвітлено у працях О. Барановської, Н. Бібік, С. Бондар, М. Бурди, Г. Васьківської, Н. Головко, М. Головка, К. Гораш, Ю. Дорошенка, Т. Засєкіної, І. Срмакова, В. Кизенка, О. Корсакової, С. Косянчука, В. Кременя, Л. Липової, О. Ляшенка, В. Паламарчук, О. Пехоти, О. Савченко, А. Самодрина, О. Топузова, С. Трубачевої, Д. Чернілевського, О. Чорноус, В. Якуніна та ін. Технологічність освітнього процесу, на думку науковців (О. Беспалько, М. Кларін, В. Євдокимов, В. Ортинський, О. Пєхота, С. Сисоєва, П. Підкасистий, Д. Чернілевський), виступає показником його якості, оптимальності, науковості. Зокрема, науковці відділу дидактики Інституту педагогіки НАПН України порушують проблеми навчання у контексті фундаменталізації, технологізації, інтеграції змісту освіти (О. Барановська, Г. Васьківська, Н. Захарчук, В. Кизенко, С. Косянчук, О. Кравчук, С. Трубачева) $[1 ; 2 ; 4 ; 7-12]$. У колективній монографії «Фундаменталізація змісту освіти у старшій школі в умовах профільного навчання» зазначається, що профільне навчання спрямоване на формування цілісної особистості та розвитку життєвої, світоглядної, наукової, культурної і професійної компетентностей учнів [13]. 
3 розвитком інформаційного суспільства наприкінці XX ст. зазнала концептуального піднесення теорія інноваційного навчання, що змінило пріоритети освітніх закладів. Почали створювати заклади нового типу, у яких активно експериментувалися та впроваджувалися нові педагогічні технології. У суспільстві поступово розпочався перехід від знаннєво орієнтованого навчання до особистісно орієнтованого. Проте поки ще існує низка суперечностей, а саме: між глобальними планами впровадження технологій профільного навчання в освітній процес закладів загальної середньої освіти та відсутністю відповідної бази для його впровадження, у тому числі - цілісної теоретичної бази; між рівнем вимог до підготовки абітурієнтів гуманітарного профілю та реальним рівнем готовності випускників (що вимагає впровадження низки педагогічних технологій за гуманітарним спрямуванням); між кількістю існуючих педагогічних технологій різних видів і реальною потребою сучасних закладів загальної середньої освіти у проектуванні та впровадженні технологій гуманітарного спрямування. Аналіз джерел з проблеми дослідження засвідчує відсутність на сучасному етапі комплексного вивчення питань, пов'язаних саме з проектуванням та реалізацією педагогічних технологій в умовах нової української школи, що вимагає подальших наукових пошуків. Тому активне впровадження профільного навчання в умовах розвитку нової української школи тягне за собою зміни змісту і технологій навчання.

Формулювання цілей статті. Метою статті є доведення тези, що технологізація освітнього процесу в старшій школі сприяє підвищенню його якості, глибшому використанню потенціалу закладів загальної середньої освіти, ширшому впровадженню інноваційних підходів, сучасних розвивальних засобів, методів, форм навчання у педагогічний процес.

Виклад основного матеріалу. Конщептуальне резюме. Відтворення і постійне оновлення інтелектуального потенціалу України вимагає розробки принципово нової концепції розвитку учнівської молоді, конструювання спеціальних надпрограм і технологій. Виконання соціального замовлення - стати державою інтелектуальних ідей і технологій - вимагає нової теорії інноваційної освіти, компонентами якої є сучасні філософські, аксіологічні, семантичні, фізіологічні, психолого-педагогічні погляди на людину. Проблема інтелектуального розвитку особистості повинна базуватись на широких системних філософських поглядах: концепціях синергетики, життєтворчості, діалогу культур та ін. Інтелектуальна творчість - це механізм, який забезпечує прогресивну еволюцію суспільства, розвиток нових технологій, у тому числі педагогічних. Психолого-педагогічні дослідження виявляють, що конституціональним у становленні особистості старшокласника є соціальне самовизначення - пріоритетна спрямованість, мотиви діяльності, від змісту і характеру яких залежать успішність навчальної діяльності та подальша життєтворчість. Тому основними напрямками загального розвитку старшокласників можна вважати інтелектуальний, соціальний і валеологічний. Сутнісними характеристиками інтелектуального розвитку учнів $є$ їхні академічні досягнення і рівень розвитку інтелектуальних умінь, а в старшому шкільному віці - рівень опанування адекватними методами наукового пізнання. Соціальний компонент розвитку старшокласника характеризується відповідною професійною спрямованістю, схильністю до конкретних дій, самостійності, відповідальності. Валеологічний компонент загального розвитку людини характеризується станом здоров'я і фізичного розвитку, які також значно відрізняються в різних умовах життя. Компоненти загального розвитку, як складники системи, перебувають між собою у взаємозв'язках та взаєморозвитку. Продуктивність взаємозв'язку навчання і розвитку залежить від раціональної реалізації стратегічних принципів реформованої школи: гуманітаризації, інтеграції, життєтворчості, оптимізації, особистісної орієнтації, єдності національного і загальнолюдського, а також відомих дидактичних принципів науковості, доступності, наочності тощо. Інтелектуальний і соціальний розвиток старшокласника, спрямовуючись метою і змістом освіти, практично реалізується через моделювання, навчальні технології [9, с.36-43].

Широке застосування педагогічних технологій в умовах нової української школи має бути зумовлено сучасними тенденціями ії розвитку: розвитком творчих здібностей, оволодінням сучасними методами наукового пізнання, прогностичними методами, методом моделювання та ін.

Метод моделювання $є$ дуже продуктивним методом формування мислення в учнів-старшокласників, велике значення має застосування моделей-еталонів, користуючись якими вчитель може прогнозувати педагогічні ситуації. Праксеологічна модель, яка відображує основну стратегію фор- 
мування мислення, містить у собі такі компоненти: мислення формується у діяльності, в єдності знання, дії зі знанням, виражається у слові. Особливо важливими для формування мислення $є$ закони та закономірності, засвоєння основних світоглядних теорій, методологічних знань, які включають в себе знання провідних методів і прийомів пізнавальної та практичної діяльності. Система основних прийомів мисленнєвої діяльності містить у собі такі компоненти: виділення головного, порівняння, узагальнення та систематизація, конкретизація, виділення і пояснення понять, доведення й спростування, моделювання, системний підхід. Така система мисленнєвих прийомів вимагає чітких етапів іiі формування: кумуляції, діагностики, мотивації, осмислення сутності та правила користування прийомом, застосування, перенесення. Таким чином, створюється чітка технологія формування мисленнєвих (інтелектуальних) умінь та навичок (компетентностей), яка стає необхідною на етапі створення нової української школи $[9 ; 10]$.

Отже, поняття «педагогічні технології навчання» не нове, але саме технологічний підхід для розбудови нової української школи є провідним і викликає цілий комплекс змін. Роль дидактики у розробці теорії педагогічної технології для нової української школи полягає у тому, що саме вона зумовлює необхідність пошуку раціональних шляхів навчання, розробляє наукові тенденції та підходи, систему закономірностей, базових принципів і обгрунтовує особливості їхньої реалізації в освітньому процесі.

Спільними ознаками педагогічних технологій $є$ системність, процесуальність, направленість на проектування та ефективність. Специфічні ознаки можуть бути різноманітними, зокрема, такими, як цілепокладання, економічність, алгоритмічність, результативність, цілісність та інші.

Розглянемо основні методологічні вимоги до проектування педагогічних технологій в умовах нової української иколи: концептуальність (існування концептуальної бази, яка має включати філософське, психологічне, дидактичне та соціально-педагогічне обгрунтування досягнення освітніх цілей); системність (мета, чітка процесуальність, взаємозв'язок, цілісність); керованість (цілі, мета, планування, етапність, зворотний зв'язок); иілісність (наявність усіх обов'язкових елементів); інноващійність (мають містити нові досягнення педагогічної науки і практики); відтворюваність (алгоритмічність, прозорість, доступність, структурованість); ефективність (результативність, оптимальність, гарантія досягнення певного стандарту навчання); конкурентноздатність у сучасних умовах $[1-3 ; 4 ; 7 ; 8 ; 11-13]$. аспектів:

Різні підходи до сутності поняття педагогічної технології зводяться до кількох спільних

1) проект певної педагогічної системи, що може бути реалізована на практиці (В. Беспалько);

2) соціальні перетворення і нове педагогічне мислення, наука (Г. Селевко); (О. Пєхота);

3) психологічно і валеологічно обгрунтований та інструктований навчальний процес

4) принципи і способи оптимізації освітнього простору (М. Кларін).

Отже, педагогічна технологія - це (у широкому сенсі) програма чи проект певної педагогічної діяльності, що послідовно реалізується на практиці; планове послідовне практичне втілення попередньо спроектованого педагогічного процесу (Беспалько В., Селевко Г. ) [3; 11]. Конкретні тлумачення цього поняття включають у себе сукупності основних методів (науково обгрунтованих способів діяльності), спрямованих на досягнення мети; сукупності дій, операцій та процедур, що інструментально забезпечують отримання прогнозованого результату (Антонова О., Кларін М., Сластьонін В. та ін.).

Таким чином, можна вважати, що поняття «педагогічна технологія» базується на відповідних концепціях навчання, комплексі принципів навчання, зокрема, системності та інших. Дане поняття можна розглядати як інтегративну систему, щзо містить иілісний комплекс методів, дій та операчій (за умови педагогічної майстерності вчителя,) які спрямовані на гарантоване досягнення дидактичних иілей - розвиток особистості учня, формування його мотиваційного, рефлексійного, інтелектуального та особистісного компонентів $[1 ; 2 ; 9 ; 10]$. Ми розуміємо поняття «технологія освітнього процесу» як моделювання його змісту, форм і методів згідно поставленої мети [9, с. 139].

Основними педагогічними технологіями, що задіяні в полі освіти України, є: змістовно-операційна технологія розвитку; технологія міжпредметної інтеграції та міжпредметні зв’язки; розвивальне 
навчання; ігрові технології; технології інтерактивного навчання; технологія проектного навчання; технологія життєвого проекту та життєвого проектування; технологія особистісно орієнтованого уроку; технологія розвитку критичного мислення; технологія формування та розвитку творчої особистості; навчання в співробітництві (командна, групова робота) та багато інших [1-4; 7-12]. Кожна 3 них є певною підсистемою в загальній системі сучасних навчальних технологій і має свій концепт, мету і завдання, основні поняття, зміст, умови реалізації. Класифікація технологій навчання постійно змінюється, але деякі з них залишаються провідними і в умовах нової української школи. Розглянемо деякі з них нижче.

Технологія змістовно-операційного розвивального навчання (В. Паламарчук) концептом має ідею про співвідношення прямого та побічного продуктів діяльності (розвиток учнів має бути основним продуктом діяльності, як і предметні знання). Принципами реалізації цієї технології є цілеспрямування, міжпредметність, активність навчально-розвивальної діяльності в умовах мотиваційного забезпечення, випереджального навчання, операційно-системного формування, поетапності. Її технологічною реалізацією є програма і технологія розвитку інтелектуальних умінь учнів для усіх класів школи. У програмі виділяються такі блоки:

I. Сприймання і осмислення інформації (аналіз і виділення головного; порівняння).

II. Узагальнення, систематизація, оцінка (узагальнення і систематизація; визначення понять, оцінка; конкретизація; доведення і спростування).

III. Творчі вміння. Технологія розвитку інтелектуальних умінь учнів має відбуватися за такими етапами: кумуляція; діагностика; мотивація; рефлексія; відпрацювання; узагальнення та систематизація; перенесення [9, с. 43-62; 10].

Упровадження педагогічної технології інтегрованого навчання, яка по суті є комплексним засобом підвищення якості та ефективності процесу навчання на засадах інтеграції, дає можливість якнайбільше враховувати інтереси, схильності і здібності учнів, поглиблювати їхні знання, зменшити навантаження, уникнути зайвої інформації у змісті непрофільних предметів, формувати наукову картину світу, створювати можливості для орієнтації освіти старшокласників відповідно до їх професійних інтересів і намірів щодо продовження освіти. Наразі активно впроваджуються інтегровані курси в старшій школі, певні особливості матимуть також форми і методи навчання, які використовуватимуться в профільній школі. Існуюча суперечність між рівнем вимог до абітурієнтів закладів вищої освіти, наприклад, гуманітарного (філологічного) профілю та реальним рівнем підготовленості випускників закладів загальної середньої освіти до вступу у відповідні заклади вищої освіти вимагає впровадження низки педагогічних технологій за гуманітарним та соціальним спрямуваннями на профільному рівні. Саме тому необхідно розробляти дидактичні моделі реалізації педагогічних технологій в умовах профільного навчання за природничим, гуманітарним, соціальним та іншими спрямуваннями [1; 2].

Важливими особливостями реалізації педагогічних технологій навчання в умовах нової української школи є те, що вони мають працювати у перехідний період іiі функціонування, забезпечувати освітній процес в умовах профільного навчання, виконувати різноманітні завдання відповідно до постійних змін у змісті навчання, пов'язувати навчальні процеси у закладах загальної середньої освіти та закладах вищої освіти [1;2;4;5;7;8;10;12;13].

Висновки та перспективи подалыших досліджень. Отже, інтелектуальний і соціальний розвиток старшокласника, спрямовуючись метою і змістом освіти, практично реалізується через педагогічні технології. Кожна 3 них є певною підсистемою у загальній системі сучасних навчальних технологій і має свій концепт, мету і завдання, основні поняття, зміст, умови реалізації. Класифікація технологій навчання постійно змінюється, але деякі з них залишаються провідними i в умовах нової української школи. Це, зокрема, технологія змістовно-операційного розвивального навчання, технологія інтегрованого навчання, які по суті є комплексним засобом підвищення якості та ефективності процесу навчання, спрямовані на взаємозв'язок навчання і розвитку учнів, сприяють формуванню єдиної картини світу, націлені на гуманізацію та гуманітаризацію навчання. Прогнозується, що технології розвивального типу та інтеграції будуть активно впроваджуватися саме у профільній школі і сприятимуть професійній орієнтації учнів, формуванню ключових компетентностей, розвитку в них навичок самоосвіти, самоаналізу, самоконтролю, самооцінки, вимагатимуть застосування надпредметних умінь. 


\section{Використані джерела}

1. Барановська О. В. Дидактичний контекст та особливості реалізації педагогічних технологій в умовах профільного навчання [Didactic context and peculiarities of pedagogical technologies in the profile education] / Барановська О. В., Косянчук С. В., Трубачева С. Е., Чорноус О. B. // Polish Science Journal. - Warsaw : Sp. z o. o. «iScience», 2018. - Issue 3. - P. 62-72.

2. Барановська О. В. Форми навчання в профільній школі // Біологія і хімія в школі. - 2007. - № 4 C. $38-41$.

3. Беспалько В. П. Слагаемые педагогической технологии / В. П. Беспалько - М.: Педагогика, 1993. - 213 с.

4. Васьківська Г. О. Метапредметний підхід до формування системи знань про людину як один із принципів сучасного підручникотворення / Г. О. Васьківська // Проблеми сучасного підручника : зб. наук. праць / [ред. кол.; наук. ред. - О. М. Топузов]. - К. : Пед. думка, 2012. - Вип. 12. - С. 42-50.

5. Гораш К. В. Комплексний підхід до прогнозування розвитку повної загальної середньої освіти / К. В. Гораш // Український педагогічний журнал. - № 4. - 2017. - С. 52-59.

6. Закон України «Про освіту» [Електронний ресурс] Відомості Верховної Ради (ВВР). - 2017. - № 38 39. - Режим доступу: http://zakon0.rada.gov.ua/laws/show/2145-19.

7. Кизенко В. Технологічний підхід до реалізації профільного навчання: психодидактичний ракурс/ Василь Кизенко// FOLIA COMENIANA: Вісник Польсько-української науково-дослідницької лабораторії психодидактики імені Я. А. Коменського/ гол. ред. Осадченко І. І. - Умань: ФОП Жовтий О. О., 2017. - C. 42-45.

8. Косянчук С. В. Технологический подход к процессу формирования ценностно-смысловых ориентаций старшеклассников/ С. В. Косянчук // Univers Pedagogic. - 2014. - №1 (41). - С. 53-60.

9. Паламарчук В. Ф. Першооснови педагогічної інноватики. Т.1. - К.: Знання України, 2005. -420 с.

10. Паламарчук В. Ф. Школа учит мыслить / В. Ф. Паламарчук. - Издание 2-е, дополненное и переработанное. - Москва : Просвещение, 1987. - 208 с. - (Библиотека заместителя директора школы по учебно-воспитательной работе).

11. Селевко Г. К. Современные образовательные технологии. - М.: Народное образование, 1998. - 256 с.

12. Трубачева С. Е. Дослідницькі технології як засіб реалізації метапредметного підходу в навчанні [Research technology as a means of metadisciplinary approach in education]. Біологія і хімія в рідній школі. - 2015. - №3. - С. 34-38.

13. Фундаменталізація змісту освіти у старшій школі: теорія і практика: кол. монографія/ [авт. кол.: Г. О. Васьківська, В. І. Кизенко, С. Е. Трубачева, С. П. Бондар, Л. А. Липова, О. В. Барановська, С. В. Косянчук, Н. В. Захарчук]; за наук. ред. д-ра пед. наук Г. О. Васьківської. Київ: Пед. думка, 2015. 288 с.

\section{References}

1. Baranovska O. V. Dydaktychnyi kontekst ta osoblyvosti realizatsii pedahohichnykh tekhnolohii v umovakh profilnoho navchannia [Didactic context and peculiarities of pedagogical technologies in the profile education] / Baranovska O. V., Kosianchuk S. V., Trubacheva S. E., Chornous O. V. // Polish Science Journal. - Warsaw : Sp. z o. o. "iScience", 2018. - Issue 3. - P. 62-72.

2. Baranovs'ka O. V. Mizhpredmetni zv'jazky u pidruchnyku dlja profil'noi' shkoly: praktychna zorijentovanist' ta tehnologizacija / O.V.Baranovs'ka // Problemy suchasnogo pidruchnyka : zb. nauk. prac'/ [red. kol.; golov. red. - O. M. Topuzov]. - K.: Pedagogichna dumka, 2016. - Vyp. 16. - 488 s. - S. $17-26$.

3. Bespal'ko V. P. Slagaemыe pedagogycheskoj tehnologyy/ V. P. Bespal'ko - M.: Pedagogyka, 1993. - 213 s.

4. Vas'kivs'ka G. O. Metapredmetnyj pidhid do formuvannja systemy znan' pro ljudynu jak odyn iz pryncypiv suchasnogo pidruchnykotvorennja / G. O. Vas'kivs'ka // Problemy suchasnogo pidruchnyka : zb. nauk. prac'/ [red. kol.; nauk. red. - O. M. Topuzov]. - K. : Ped. dumka, 2012. - Vyp. 12. - S. 42-50.

5. Gorash K.V. Kompleksnyj pidhid do prognozuvannja rozvytku povnoi' zagal'noi' seredn'oi' osvity / K. V. Gorash // Ukrai'ns'kyj pedagogichnyj zhurnal. - № 4. - 2017. - S. 52-59.

6. Zakon Ukrai'ny “Pro osvitu” [Elektronnyj resurs] Vidomosti Verhovnoi' Rady (VVR). - 2017. - № 38-39. Rezhym dostupu: http://zakon0.rada.gov.ua/laws/show/2145-19.

7. Kyzenko V. Tehnologichnyj pidhid do realizacii' profil'nogo navchannja: psyhodydaktychnyj rakurs / Vasyl' Kyzenko // FOLIA COMENIANA : Visnyk Pol's'ko-ukrai'ns'koi' naukovo-doslidnyc'koi' laboratorii' psyhodydaktyky imeni Ja. A. Komens'kogo / gol. red. Osadchenko I. I. - Uman' : FOP Zhovtyj O. O., 2017. S. 42-45.

8. Kosjanchuk S. V. Tehnologycheskyj podhod k processu formyrovanyja cennostno-smыslovыh oryentacyj starsheklassnykov / S. V. Kosjanchuk // Univers Pedagogic. - 2014. - №1 (41). - S. 53-60. 
9. Palamarchuk V. F. Pershoosnovy pedagogichnoi' innovatyky. T.1. - K.: Znannja Ukrai'ny, 2005. - 420 s.

10. Palamarchuk V. F. Shkola uchit myslit' / V.F. Palamarchuk. - Izdanie 2-e, dopolnennoe i pererabotannoe. - Moskva: Prosveshchenie, 1987. - 208 s. - (Biblioteka zamestitelya direktora shkoly po uchebno-vospitatel'noj rabote).

11. Selevko G. K. Sovremennыe obrazovatel'nые tehnologyy. - M.: Narodnoe obrazovanye, 1998. - 256 s.

12. Trubacheva S. E. Doslidnyc'ki tehnologii' jak zasib realizacii' metapredmetnogo pidhodu v navchanni [Research technology as a means of metadisciplinary approach in education]. Biologija i himija v ridnij shkoli. -2015 . - №3. - S. 34-38.

13. Fundamentalizatsiia zmistu osvity u starshii shkoli: teoriia i praktyka: kol. monohrafiia/[avt. kol.:H. O. Vaskivska, V. I. Kyzenko, S. E. Trubacheva, S. P. Bondar, L. A. Lypova, O. V. Baranovska, S. V. Kosianchuk, N. V. Zakharchuk]; za nauk. red. d-ra ped. nauk H. O. Vaskivskoi. Kyiv: Ped. dumka, 2015. 288 s.

Паламарчук В. Ф., доктор педагогических наук, профессор, научный консультант гимназии «Троешина» Деснянского района г. Киева

Барановская $\boldsymbol{E}$. В., кандидат педагогических наук, стариий научный сотрудник отдела дидактики Института педагогики НАПН Украинь

\section{ПЕДАГОГИЧЕСКИЕ ТЕХНОЛОГИИ ОБУЧЕНИЯ В УСЛОВИЯХ НОВОЙ УКРАИНСКОЙ ШКОЛЫ: ВЕКТОР РАЗВИТИЯ}

Статья посвящена проблеме технологизации образовательного процесса в условиях новой украинской школы с целью повышению его качества; оптимального использования потенциала учреждений общего среднего образования; широкого внедрения в педагогический процесс инновационных подходов, современных развивающих средств, методов и форм обучения. Авторами проведен анализ предмета педагогической технологии, рассмотрена сущность, ее виды и различные аспекты внедрения технологического подхода в учреждениях общего среднего образования в условиях профильного обучения. Доказана ценность теории педагогической технологии для новой украинской школы, необходимость поиска рациональных путей обучения, разработки современных тенденций, базовых принципов и обоснования особенностей их реализации в условиях новой украинской школы.

Ключевые слова: новая украинская школа; профильное обучение; педагогическая технология; интеллектуальное развитие личности.

Palamarchuk V., Doctor of Pedagogical Sciences, Professor, scientific consultant of the Gymnasium «Troieshchyna» of Desnyanskyi district, Kyiv

Baranovska O., Candidate of Pedagogical Sciences (PhD), Senior Researcher, Senior Researcher at the Didactics Department, Institute of Pedagogy of the NAES of Ukraine

\section{PEDAGOGICAL TECHNOLOGIES OF TEACHING UNDER THE CONDITIONS OF THE NEW UKRAINIAN SCHOOL: VECTOR OF DEVELOPMENT}

The article is devoted to the analysis of the concept of "pedagogical technology" and its place in the conditions of the development of the new Ukrainian school. The purpose of the article was to prove that the technological development of the educational process in high school contributes to the improvement of its quality, the profound use of the potential of general secondary educational institutions, the wide introduction of innovative approaches, modern developmental tools, methods, and forms of teaching in the pedagogical process. A complex of research methods was used, among them: theoretical analysis, synthesis, comparison, modeling. The author considers the essence and types of pedagogical technologies, various aspects of the introduction of the technological approach in institutions of general secondary education in conditions of profile education. The importance of the theory of pedagogical technology for the new Ukrainian school, the need to search for rational ways of teaching, the development of modern trends, basic principles and justification of the features of their implementation in the conditions of the new Ukrainian school is being proved.

Key words: new Ukrainian school, profile education, pedagogical technology. intellectual development of a personality. 